\title{
PUBLIC SERVICE ACCOUNTABILITY IN TATANGA DISTRICT OFFICE, PALU CITY (STUDY OF SERVICES ID CARD MANAGEMENT)
}

\author{
M. Kafrawi Al-Kafiah; Muhammad Ahsan Samad; La Husein Zuada \\ Tadulako University \\ E-mail:
}

M.kafrawi_alkafiah@yahoo.com; ahsansamad@untad.ac.id; husenzuada@untad.ac.id

\begin{abstract}
The objectives of this study is analyzing accountability of public service in management Identity Card at tatanga District Office and the obstructed factors. The method used in this study is qualitative research, to describe the phenomena based on the fact in the research focus. The population of this study is the stake holders of Tatanga District and the public service users. Sample selection used purposive technique by selecting 6 (six) informants. Technique of data collection in this study consists of observation, interview and document. The result of the study showed that the accountability of public service in management Identity Card at the office of Tatanga District was less maximal. This was proved by 3 (three) indicators considered to be a starting point, they are service reference, attention to the public and solution. Only 1 (one) indicator showed the accountability of service is the solution. It was given by the government of the Tatanga District for the public service users had been maximally implemented. While indicator of service reference and attention to the public has not got maximal categories yet. The factors that obstructed the accountability of public service in management Identity Card at Tatanga District office which is found in this study wereunavailability of equipment to create ID card. Thus, the duty of the District government officials in service only confined to ID cards. Then the people have to complete it to another district office or Civil Registration in Hammer. Besides, the service provided from district government in management Identity Card is still oriented on arrangement or simply impressed very normative, less committed to adjust servicing values or norms that exist in society in order to create a quality of service that is oriented on customer satisfaction.
\end{abstract}

Key Words: Accountability, Service, They are Service Reference, Attention to the Public, Solution. 


\section{INTRODUCTION}

Government officials must also continuously improve their performance and be accountable to the public, especially with regard to all attitudes, behaviors, actions, and policies that have been, are being, and will be made to the public. Their accountability must be conveyed openly and transparently to the public (Joko Widodo, 2006:4). Every state governance must be accountable to the public (public accountability) as the holder of the highest sovereignty. Thus, the application of the principle of accountability in the administration of the state must be fulfilled by government officials who are mandated to run the state bureaucracy.

Accountability is an obligation to convey accountability or to answer and explain the performance and actions of a person/legal entity/collective leader of an organization to parties who have the right or authority to ask for information or accountability. (LAN: Page 43).

The low accountability of the government bureaucracy in public services, and lack of high responsiveness to the needs of the community is due to the less than optimal performance of the bureaucracy. Ismail Mohamad (2009: 23) argues that "the performance of the bureaucracy that is still not optimal is realized as a result of the high level of disciplinary violations and the level of abuse of authority in the form of corruption. This fact is accentuated by the number of public complaints regarding procedures and certainty, responsibility, morale of officers, as well as the emergence of illegal levies that increase service costs, as well as the low professionalism of government officials in carrying out their duties and functions.

The various phenomena above show how weak the trust and legitimacy of the government and its bureaucracy is in the eyes of the public. For this reason, adequate bureaucratic resources are needed or public service providers who have high accountability in carrying out all government institutional activities.

\section{THEORETICAL VIEW}

Based on the main idea above, to overcome various problems in building an accountable public service image, the government has set various regulations and policies that regulate the general principles of state administration. Law No. 28 of 1999 concerning the Implementation of a Clean 
State Free from KKN regulates the principles of state administration which include the principle of legal certainty, the principle of orderly state administration, the principle of public interest, the principle of openness, the principle of proportionality, the principle of professionalism and the principle of accountability (LAN, 2000: 2). Furthermore, the explanation of the principle of accountability in Law No. 25 of 2009 concerning Public Services mandates that the process of service delivery must be accountable in accordance with the provisions of the legislation (Article 4 letter i).

The sub-district government organization as a leading government institution in providing services to the community is one of the district/city government apparatus that has a very strategic position, task and function in the context of implementing government and development activities in the region. In connection with that, the Tatanga District government organization which is the locus of the author's research, of course the issue of accountability in providing services to the community needs to be the attention of the Palu City government in order to improve the performance of sub-district government organizations.

Tatanga sub-district as one of the sub-districts formed in 2012 based on theRegional Regulation Number 4 of 2012 concerning the Expansion of Subdistricts is the result of the division of the South Palu Subdistrict which covers 6 villages namely Tavanjuka Village, Palupi Village, Pengawu Village, Duyu Village, Boyaoge Village and Nunu Village. Thus, the structuring of the institutional structure should be accompanied by efforts to increase the implementation of public service accountability.

From the results of preliminary observations at the research locus, it shows that in reality the Tatanga District government has not implemented an accountability system according to applicable norms or provisions, thus causing ineffectiveness and inefficiency of services, not being transparent about the certainty of time and service costs, so that public services are provided. by the Tatanga District government officials have not been able to answer the developments and public needs.

The types of public services in the form of administrative services carried out by the Tatanga District government apparatus are population administration services such as Identity Cards (KTP), certificates and legalization of permits, Land Deeds, Business Permit Recommendations and others. 
Of the several types of services, one type of service that stands out is the ID card service, this is due to the significant number and frequency of service delivery to the public. Based on data obtained from the Tatanga District Office, the number of KTP processing services for the period 2018 to 2019 reached 934 people (Tanganga District Office: 2019). In addition, it has a very broad impact on the public, because the ID card service is a mandatory service for every resident who has met the requirements and its existence is a requirement to access various services and other affairs. Because the KTP management service activity is one type of public service, from the aspect of the service it must be carried out in an accountable manner.

Based on the description above, the authors argue that the accountability of public services at the Tatanga District Office, especially in terms of managing ID cards which will be highlighted in this study is one of the important aspects in efforts to improve service accountability that is transparent, fast and precise in the context of developing the quality of governance. in Neighboring District in particular and Palu City in general. Therefore, the problem of accountability in the management of ID cards is made as a study in research.

From the above background, problems related to the accountability of the KTP management service at the Tatanga District Office will be studied which are formulated as follows: (1) Is the Accountability of the KTP Management Service at the Tatanga District Office in accordance with Standard Operating Procedures, both seen from the service reference, attention to public and the solutions provided by the sub-district government to customers. (2). Do these three factors have a contribution to the KTP service and what are the factors that hinder the accountability of the KTP management service?

The general objectives of this study are: (1). To find out the accountability of public services in managing ID cards at the Tatanga District Office, Palu City. (2). To find out what factors hinder the accountability of public services in managing ID cards at the Tatanga District Office, Palu City.

The benefits of this research can be seen theoretically and practically.(1). Theoretically, the results of this study can be used as a reference and a useful source of information for further research and also the results of this study can contribute to the development of public administration science. (2). Practically. The results of this study can be used as a contribution of thought for decision makers in the field of government in an effort to develop the performance of 
government institutions and increase government apparatus resources. And the results of this study can be used as input for government administrators in Palu City in an effort to increase public service accountability in the fields of government, development and society.

Meanwhile, in this study, the focus of this study is on accountability of public services according to Dwiyanto (2002: 14), namely service reference, attention to the public, and solutions. The service reference is in the form of service procedures used in the process of providing services to the service user community sequentially starting from the activities carried out when the service user community arrives until the service is completed. Attention to the public is to show that the bureaucratic apparatus must ensure that all work activities are solely to provide services that satisfy the service user community. The solution is an action that must be taken by the bureaucratic apparatus in service to the service user community who does not meet the provisions.

\section{RESEARCH METHOD}

This type of research is qualitative research. According to Sugiyono (2008:8) qualitative research is a research method used to examine the condition of natural objects, where the researcher is the key instrument. Kirk and Miller in Lexy J. Moleong (2004:3) argue that "qualitative research is a particular tradition in social science that fundamentally depends on observing humans in their own area and relating to these people in their language and terminology".

By using qualitative research methods, the authors can study, describe and know in depth how the accountability of public services at the Tatanga District Office in managing ID cards.

In this study, the researchers took the location at the Tatanga District Office, Palu City, taking into account the time and proximity of the researcher to the research location, making it very easy for data collection purposes in the field. In addition, the Tatanga District Office is one of the foremost parts of local government institutions to provide services to the community. While the length of time the research will be carried out for 4 months, namely from June 2019 to October 2019. 
Determination of informants in a purposive manner prioritizes service providers, in this case the Tatanga District Government officials and the community who use services in managing ID cards. The informants determined by the researchers from elements of the sub-district government consisted of the Tatanga sub-district head, the head of the Tatanga sub-district government section. Meanwhile, from the community element, service users consist of 4 people who have managed ID cards.

In this study, the concept used is public service accountability as measured by the focus of the study as follows:

\section{A. Service Reference}

The service reference used by the Tatanga District Government apparatus in the process of providing public services. The focus of this study reflects the principle of service orientation developed by the apparatus towards the service user community. The service reference can be in the form of service standards or Standard Operating Procedures (SOPs) used by the Tatanga District Government officials in the service process for managing ID cards.

\section{B. Attention to the Public}

Attention to the public in carrying out service tasks, namely the use of resources and how far the interests of the service user community get priority from the Tatanga District Government apparatus in carrying out KTP management services.

\section{Solution}

The solution is in the form of actions taken to provide convenience to the service user community when experiencing difficulties in service.

In this connection the researchers used the types and sources of data, namely:

1. Primary data, the source is through observation and interviews conducted by researchers by providing structured interview guidelines to informants.

2. Secondary data, namely data sourced from the Tatanga District Government Office, especially written documents, regarding the operationalization of service delivery to the public as well as 
descriptions of research locations such as the location of the Tatanga district, the number of officers, facilities and infrastructure supporting services that support the research results.

The techniques used in this research are as follows:

\section{Observation (Observation)}

Data collection through observation is carried out through direct observation and recording of the research object in order to obtain actual data from data sources in the field. This method is taken by observing directly or indirectly specifically about the accountability of KTP services.

\section{E. Interview (Interview)}

In the in-depth interview process, the researcher will use notes and a recording device or tape recorder as long as the informant is willing. Interviews were conducted with informants of the Tatanga District Government Officials and public service users who were found during the research using an "interview guide".

\section{F. Documentation}

In each research implementation always try to get as much data as possible in the hope that the data that has been collected will answer the existing problems by analyzing the data.In accordance with the research objectives, the data analysis method used is qualitative data analysis. In this study, the researcher will use an interpretation analysis approach. The technique of this analytical approach is to bring up what it means or the meaning of the problem, case, situation or situation under study. Here, the opinion of one informant will be compared with another, related to the relevance of the objectives and research questions and processed the data into a certain understanding. Thus the researchers obtained a comprehensive picture of the Accountability of KTP management services at the Tatanga District Office, Palu City.

\section{RESULTS AND DISCUSSION}

In principle, the existence of a bureaucracy in the public sector is to provide services to the community where in carrying out its mission, goals and programs the principles of transparency, 
accountability, efficiency and effectiveness are adhered to, so that the community receives optimal services from the government.

In this connection the KTP management service is one type of public service provided by the government which is included in the administrative service group that produces the form of official documents needed by the community.

In accordance with their position, main tasks and functions, sub-district government organizations have a strategic role in providing services to the community because they are in a leading position as an autonomous regional apparatus that deals directly with the community in providing services. Therefore, to what extent is accountability as one of the basic principles in realizing good governance, it must be used as a guide in every service activity carried out by government officials, including services in terms of managing ID cards carried out by the subdistrict government.

This study will examine how the accountability of public services in managing ID cards at the Tatanga District Office by using several focus studies of research variables so that phenomena related to accountability in service delivery can be disclosed. Each focus of the study as explained in the flow of thought and concept definition will be examined in depth, so that observations and interviews conducted on the object of research will result in responses from informants regarding service accountability in managing ID cards. This can be stated through the focus of service accountability studies which include:

\section{A. Service Reference}

The service reference used by the Tatanga District Government apparatus in public services is a guideline that reflects the service orientation principle developed by the sub-district government apparatus towards the service user community. There are two parameters used to measure the reference for public services, namely: First, the Standard Operating Procedure (SOP) and how it is implemented. Reference services provided bydistrict government officials must be directedbased on the needs and interests of the service user community itself, and in its implementation the service procedure must be oriented to the creation of satisfaction of the service user community. Second, actiondistrict government officials against service users who do not meet service requirements, in 
Tadulako Social Humaniora Journal

Vol 3, No. 1, October 2021, pp. 51-62

this case the action refers to the service reference to help service user communities in the service process.

\section{B. Attention to the Public}

The development of public service management, including in terms of KTP services, demands an increase in the capacity of the sub-district government apparatus in providing services to the public. on increasing the equivalence between expertise with the ability and field of work of subdistrict government officials in providing services as well as the existence of facilities and infrastructure, especially in supporting the service apparatus, giving serious attention to the needs of the service user community

The parameter used to measure attention to the community is the use of resources owned by the Tatanga District Government apparatus. The use of resources is intended so that every sub-district government apparatus has a high ability and is effective and efficient in carrying out its duties and functions in providing services. Therefore, the existence of apparatus resources in the ranks of the sub-district government needs to be continuously developed, as well as the development of adequate facilities and infrastructure. In this case Malayu SP Hasibuan (1995: 76) suggests that "development is an effort to improve the technical, theoretical, conceptual, and moral knowledge of employees in accordance with the needs of the job/position through education and training".

\section{Solution}

One of the characteristics of an accountable service is a service that can provide solutions or solutions for service users who have difficulty in managing what is needed. Solution is a way of solving / solving problems without any pressure from various parties.

In reality, the service user community still often experiences difficulties in getting the best service, such as understanding the regulations, procedures that must be followed or fulfilling the required requirements. Thus, district government officials who are accountable to the service user community should be able to provide service solutions that do not make it difficult for the community. 
To measure the solution in service accountability provided by the Tatanga District Government apparatus in managing ID cards, the parameter that can be used is the actions taken by the officers when there are community service users who experience difficulties in managing ID cards.

From the results of research conducted in the field, it can be said that from the three focus of service accountability studies in the form of service references, attention to the public and solutions, it can be said that they have not made a maximum contribution to the KTP management service carried out at the Tatanga District Office. This can be seen from each focus of the study where there is only one solution, namely providing solutions to community users of ID card processing services that have been carried out optimally.

In this regard, several factors have been identified that hinder accountability in performing KTP management services at the Tatanga District Office, namely:

\section{a. KTP Making/Printing Equipment}

Equipment to process the manufacture/printing of ID cards that is not yet owned by the Tatanga District Office, so that the service for making/printing ID cards is still handled by the Department of Population and Civil Registration of Palu City, while the Tatanga District government is only limited to the management process. currently occupied is a former puskesmas building and does not have a special room that is considered suitable for placing photo shoot equipment and printing ID cards. As a result, service users tend to be reluctant to take care of their ID cards up to the Population and Civil Registration Office of Palu City because they feel they are not used to taking care of themselves. Such conditions are difficult to account for in building the quality of public services.

\section{b. Service Orientation.}

Based on observations in the field, it shows that the Tatanga District Government officialsIn providing KTP management services, it seems that they still apply standard values or service norms unilaterally. Such as the provision of services that are only oriented to a number of rules and implementation instructions, not to customer satisfaction as an element of accountability for the 
services provided by government agencies. As a result, there is a tendency that there is a weak commitmentdistrict government officials to be accountable to the people who use the services it serves.

\section{CONCLUSIONS AND RESEARCH IMPLICATIONS}

Based on the results of the research and discussion that has been described, the following conclusions can be drawn:

1. The KTP management service at the Tatanga District Office shows that it is less accountable. This is evidenced from the three focus of the service accountability studies studied, namely service references, attention to the public and solutions, only one focus of the study shows that service accountability is in the form of solutions provided by the Tatanga District Government apparatus to service users when experiencing difficulties in managing ID cards. has been maximized. Meanwhile, the focus of service reference and attention to the public is in the less than optimal category as measured by several parameters used, such as SOPs, the actions of the Tatanga District Government officials and the use of available resources as well as the priorities of the Tatanga District Government officials in providing services.

2. There are still factors inhibiting service accountability in terms of managing ID cards at the Tatanga Subdistrict Office, namely the unavailability of equipment to process ID card making/printing because Tatanga District does not have a special room that is considered adequate to place photo ID/ID card printing equipment, so the task of government officials Tatanga Sub-district in service is only limited to the management of ID cards and for the settlement, it still has to deal further with the Population and Civil Registration Office of Palu City. In addition to these factors, the services provided by district government officials in managing ID cards are still oriented to rules alone.

\section{Research Implication}

1. Efforts are needed from the Palu City Government in the not too distant future to immediately realize the construction of the Tatanga Subdistrict Office building which is considered appropriate for the implementation of public services, so that people who will 


\section{Tadulako Social Humaniora Journal}

Vol 3, No. 1, October 2021, pp. 51-62

carry out ID cards no longer have to deal with traveling such a long service distance, it is only up to only at the district level.

2. The existence of constitutional obligations from all levels of government agencies, then the sub-district government should make an orderly Government Agency Performance Accountability Report (LAKIP) at the end of each year which can be used in addition to being responsible for the government's superiors, it can also be submitted openly to the public through public media. . Thus the community can know and assess how far the performance of services provided by the sub-district government to the community.

\section{REFERENCES}

Dwiyanto, Agus, 2002, Governance Reform and Regional Autonomy, Center for Population and Policy Studies UGM. Yogyakarta.

Journal of Administration and Development, Volume 4 No. 1, January 2009, PERSADI.

LAN and BPKP, 2000, Accountability and Good Governance, State Administration Institute, Jakarta.

Malay SP Hasibuan, 1996, Basic Management of Understanding and Problems, Mount Agung, Jakarta.

Moleong, Lexy, J, 2010, Qualitative Research Methodology, Revised Edition, Rosdakarya Youth, Bandung.

Sugiyono. 2008, Research Methods for State Administration. CV. Alphabet. Bandung.

Law of the Republic of Indonesia Number 28 of 1999 concerning the Implementation of a State that is Clean and Free from Corruption, Collusion, and Nepotism

Law of the Republic of Indonesia Number 25 of 2009 concerning Public Services.

Regional Regulation Number 4 of 2012 concerning the Expansion of Districts.

Widodo Joko, 2010, Public Policy Analysis, Concepts and Applications of Public Policy Process Analysis, Bayumedia Publishing, Malang. 